\title{
Cattle to settle - bull to rule: on bovine iconography among Late Neolithic Vinča culture communities
}

\author{
Miloš Spasić \\ Belgrade City Museum, Belgrade, RS \\ spasicmilos@gmail.com
}

\begin{abstract}
Bovine iconography is one of the most important components for understanding social identities among Neolithic Vinča culture communities. It is believed that both wild and domesticated cattle were introduced into Vinča culture symbolic practice as one of the most powerful and profound metaphors of human perception of the world. I argue that the use of bovine iconography was socially structured, as was the maintenance of animals, and that the vast corpus of bovine iconography should be considered in terms of actual human-animal relationships.
\end{abstract}

IZVLEČEK - Ikonografija goveda je ena izmed najpomembnejših komponent za razumevanje družbene identitete med skupnostmi neolitske kulture Vinča. Na splošno velja prepričanje, da je bilo tako divje kot domače govedo vključeno v simbolično prakso kulture Vinča kot ena najmočnejših in temeljnih metafor človeškega dojemanja sveta. Trdim, da je bila uporaba ikonografije goveda družbeno strukturirana, kar velja tudi za oskrbo živali, in da je potrebno obsežen korpus ikonografije goveda razumeti $v$ kontekstu dejanskih odnosov med ljudmi in živalmi.

KEY WORDS - bovine iconography; Vinča culture; bucrania; figurines; human-animal relationship; symbols

\section{Introduction: human and nonhuman animals in Late Neolithic Vinča culture}

Tim Ingold (2000.61-77) brilliantly described the history of human-animal relationship as a long-term process from trust to domination. Still, the relationship between humans and animals differs significantly from place to place and from time to time, depending on various cultural, environmental and economic issues. Animal imagery in human material culture $\mathbf{1}$ actually grew out of those relationships, as well as from the numerous ways in which people understand and comprehend nature and their environment. In this paper, I argue that the main impetus for the creation of bovine iconography in Late Neolithic Vinča culture also grew out of the physicalvisceral relationships people had with cattle and from the constant reinterpretation of humans' and animals' place in the world.
In the lucid language of Douglas Bailey and others, the term Vinča culture refers to an archaeological overgeneralisation widely used to simplify the complexities of people, behaviour and material culture focusing on Serbia, western Bulgaria and southwestern Romania (Bailey et al. 2010.161). Indeed, this statement is true; humans are expert classifiers and categorisers (as cited in Parker-Pearson, Richard 1997.9; Humphrey 1984.143-145); prehistoric archaeologists succeeded in their classifying quest, and as a result different communities that share similar material culture were labelled with the term Vinča culture and were neatly catalogued in the Late Neolithic folder (Fig. 1). In reality, the similarities in the physical manifestation of the material culture are merely imaginative, while their social, cultural and

1 It is now indisputable that certain animal species also create material culture (Ingold 1983; 2000.363-364). 
ideological (sensual also) attributes differ greatly from site to site, and from period to period. 2 There are some general patterns in settlement, economy and material culture, but still there are considerable divergences which do not allow for broad generalisations. Some Vinča culture communities lived on river banks or hilltops, others at tell sites, even in caves. Some built elaborate two-story houses, others dwelt in pit-houses; some were skilled flint knappers, other specialised in copper metallurgy. Some made shiny black vessels, some matte red. At the risk of making just another redundant statement, I will again underline that the structuring and shaping of material culture occurred via a myriad of various social agents and cultural constructs.

Likewise, human-animal relationships, as well as the use of animals in the economy and in symbolic activities differed significantly. We know that the everyday lives of Vinča communi-

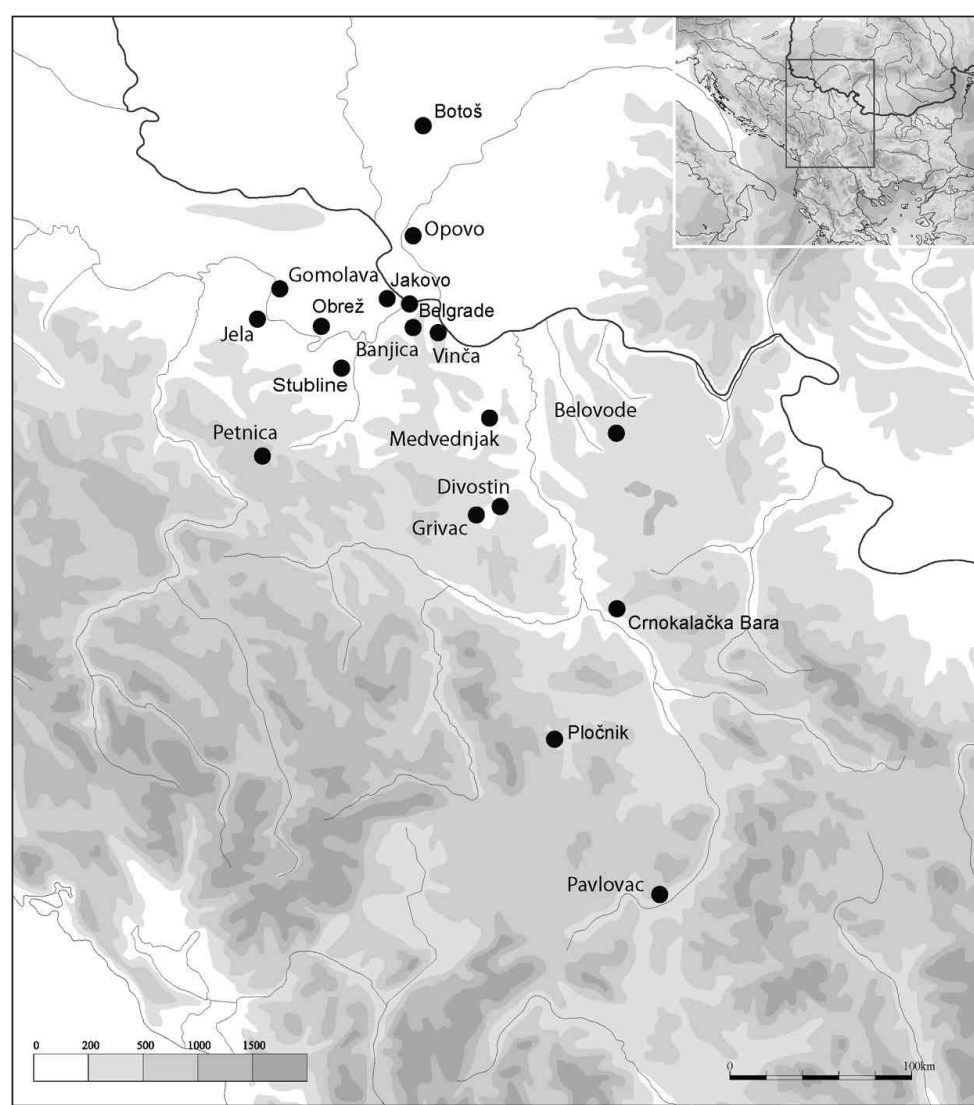

Fig. 1. Late Neolithic Vinča culture sites mentioned in the text. animals, both physically and symbolically. Domesticates were carefully nurtured, wild species were hunted, and both were the subject of vivid symbolic structuring. The list of wild and domestic animal species in Late Neolithic Vinča culture is long, and their role in the economy of different communities has been thoroughly elaborated (cf. Greenfield 1986; Bökönyi 1988; Clason 1979; Dimitrijević 2006; Orton 2008). If heuristic theses that place animal representations in the sphere of cult and religion are not to be taken seriously (cf. Gimbutas 1982) being merely anecdotal (sensu Bailey 2005. 12-15), the social and symbolic aspects of humananimal relationship were of far less interest ( $c f . R u s$ sell 1998; 1999; 2012.80; Orton 2008.292-318). Although the lives of Vinča communities were probably profoundly influenced by complicated systems of beliefs and religion, considering the current state of evidence, I see no reasonable line of inquiry which could be followed in order to comprehend animal's place in supposed Vinča culture cosmology. Certainly, some animal species (cattle, birds, deer, dogs, etc.) were introduced into the belief systems, but we are so far away from delineating some sort of ani- mal Pantheon, that it is better not to discuss it. Instead, a whole range of studies dealing with other aspects of animal symbolism in the Neolithic have proved to be very fruitful (cf. Peric 1996; Russell 1998; Whittle 2003.79-106; Borić 2005; Marangou, Grammenos 2005; Mlekuž 2007; Nanoglou 2008a; 2009; Twiss, Russell 2009).

\section{Animal iconography}

Animal representations in the Late Neolithic Vinča culture have been a subject of archaeological inquiry for more than a century. The history of the theoretical frameworks employed followed the progression of interpretations of anthropomorphic imagery, at least in the case of clay figurines. Thus, interpretations focused mainly on various questions of function and use, with these objects being seen primarily as cult instruments. This approach has not changed: Balkan archaeologists have not posed new questions concerning animal representations in Vinča culture. We just became more careful in our analysis, and as a result there is a strong decline from posing any interpretative questions concerning either human or animal imagery. There are some advan-

2 Late Neolithic Vinča culture is dated to the period 5300-4600 BC (Borić 2009). 
ces, in that more attention is paid to contextual data; but since this has not offered any progress in functional interpretation, the finds continue to be published with no inquiry that addresses some other aspects of human and animal representations. 3 We will see that in order to move away from heuristic and anecdotal explanations, we need to cast off the functional burden and change the direction of our analysis in order to respod to answerable questions.

When dealing with animal iconography in Vinča culture, the first obstacle is the identification and recognition of the species represented. Taken as whole, the interpretation of both human and animal Vinča iconography is in the deep shadow of ambiguity and vagueness. Sometimes it is even hard to determine whether it is an animal or human that is represented. We know that there are many examples of hybridism and absurdness in depicting humans and animals in Vinča culture, such that any effort to identify the exact species, gender or age is doomed to failure. It is almost as we are dealing with some sort of cultural bestiary, with representations of liminoid half-human-bird-like creatures, human-bear hybrids, cat-awls, centauries, sphinxes, etc. Therefore, although the topic of hybridism and ambiguity in Vinča iconography is very challenging, for the purposes of the present paper, I deal only with securely defined bovine representations. Even in this category, we will see that what we see is not what we think we see, and that what they thought is not what we see.

\section{Bovine imagery in Vinča culture}

It has always been assumed that the relationship between Neolithic communities and cattle was somehow significant. Both the hunted wild beasts and the well cared for and tame domesticates were indeed very important. Besides their nutritional value, cattle had potent symbolic importance for almost all Neolithic communities in the Central Balkans. ${ }^{4}$ Bovine iconography in late Neolithic Vinča culture is also very diverse. Cattle bucrania were placed on the interior and exterior walls of houses, vessels were decorated with cattle protomes, cattle astra- gals were used as loom weights, and clay bull figurines were modelled for various purposes (deities, toys, ceremonial and religious items etc.). I argue that the employment of bovine iconography was socially structured, as was the maintenance of animals themselves. It is generally believed that bull symbolism in the Neolithic had strong male associations (power, strength, fertility, prestige etc.). A comparable setting was observed among contemporary indigenous societies (Evans-Pritchard 1940.16-51) and the same stands for Neolithic Vinča culture also. However, new evidence suggests that bull iconography was clearly associated with both female and male activities. Finally, cattle iconography appears to be equally of private and public concern, and it was probably related to both genders and all ages. I argue that the vast corpus of Bos iconography should be considered in terms of actual human-animal relationships, and it is only in this way that all structural oppositions (male/female, wild/domestic, private/ communal, inside/outside) that have been observed can be understood.

Iconographic representation of cattle in Vinča culture can be divided approximately into four arbitrary categories: (i) bucrania; (ii) clay figurines; (iii) ceramic vessels; (iv) miscellaneous - this category includes loom weights, so-called Y amulets etc. As a clarification, it is notable that among the many types of animal representation, only cattle imagery has some naturalistic and realistic attributes of the species. All four categories of bovine representations could be further divided into sub-categories, but the main characteristic of all of them is the material of which they were made: clay. Almost the whole inventory of animal imagery in Vinča culture is made of clay. Stone is used very rarely and intriguingly only for the modelling of specific forms of so-called equine-like and canine-like figurines (Garašanin 1951; Antonović 2003). 5

\section{Bucrania}

Bucrania appear over a vast geographical area, from Central Asia and the Near East to Central Europe,

\footnotetext{
3 Needles to say, the significance of contextual data is enormous, but again it turned out that as if we were expecting to find speaking bucrania, or a burial with male shaman holding bull figurine and his female apprentice holding a vessel with bull protomes. Again, in order to understand the function and use of animal representations. A truth case of Pompeii premise (sensu Binfrod 1981).

4 Even since the Middle Neolithic Starčevo culture bovine representations had constituted an important part of animal iconography in the Central Balkans, with small clay and stone amulets and bull figurines as the most frequent animal representations (cf. Stanković 1989-1990; Budja 2003; Vuković 2005).

5 Anthropomorphic figurines in Vinča culture are also rarely made of stone. In contrast, stone figurines are quite common in the Late Neolithic of northern Greece (Nanoglou 2008b).
} 
and are mainly associated with Neolithic and Chalcholithic agro-pastoral communities. As defined in the literature, a bucranium is a cattle skull plastered with clay. It is most frequently part of the house inventory, placed inside the house or hung on the outer wall.6 Bucrania are highly visible items and are among the most permanent features of a house. They constitute an enduring structure, which was kept and displayed in the same part of the house for a very long time. There are numerous examples of re-plastering, re-modelling and modification of $b u$ crania in Neolithic houses. Even when houses undergo significant reorganisation, bucrania are kept and repeatedly displayed in the same place or near to where they were originally intended to be positioned. Only in later Vinča culture we have possible evidence of portable bucrania, which could be the case with an entirely clay bucranium from house $1 / 2008$ at Stubline. According to the current evidence, at least 30 bucrania have been retrieved from Vinča culture settlements in Serbia.

On morphological and purely arbitrary bases, $b u$ crania could be divided into four main categories:

(1) Bucrania with plastered skull and horns. This is the most typical, but not the most common type of bucrania. After removal from the body, the head was plastered with clay and ornamented in various ways. The horns were left unplastered, protruding from the clay covered skull. nia that appear in Vinča culture houses. Until now only three such specimens have been reported from the house 2/1979 at site of Banjica, as well as almost complete aurochs and domesticated cattle skulls with horns from a burnt Late Vinča culture house at Jela near the town of Šabac and from the pit at Gomolava.

The appearance of some of these bucrania types seems to diverge chronologically, and there are probably some differences in their meanings. According to evidence from the sites at Vinča and Jela near the town of Šabac, the bucrania with plastered skull and horns and real cattle bucrania with horns are the oldest examples, being produced at least since the Vinča $C$ period. Clay bucrania are specific to a younger phase, as attested at the sites at Stubline, Jakovo and Gomolava. The main iconographic characteristics of all the bucrania types with clay plastering are a very pronounced muzzle, eyes, and horns. Other anatomical details are rarely rendered. All the bucrania from the Serbian sites were published with insufficient or no data on the context of the find or actual archaeo-zoological analysis. In the following, I present the data on bucrania which were available to me.

\section{Banjica}

Banjica is a multi-layered settlement with horizons which correspond to the middle and late phase of Late Neolithic Vinča culture. It is situated on a gen-

(2) The second type includes clay modelled bucrania with horns. In this type, the head is modelled entirely from clay, except the horns; real horns were set in the wet mass of clay immediately after the head was modelled.

(3) Bucrania made entirely of clay are usually very small, sometimes no larger than a human fist. Usually, only the head is represented, without the horns.

(4) Horns alone and/or skull frontlets are the rarest type of bucra-

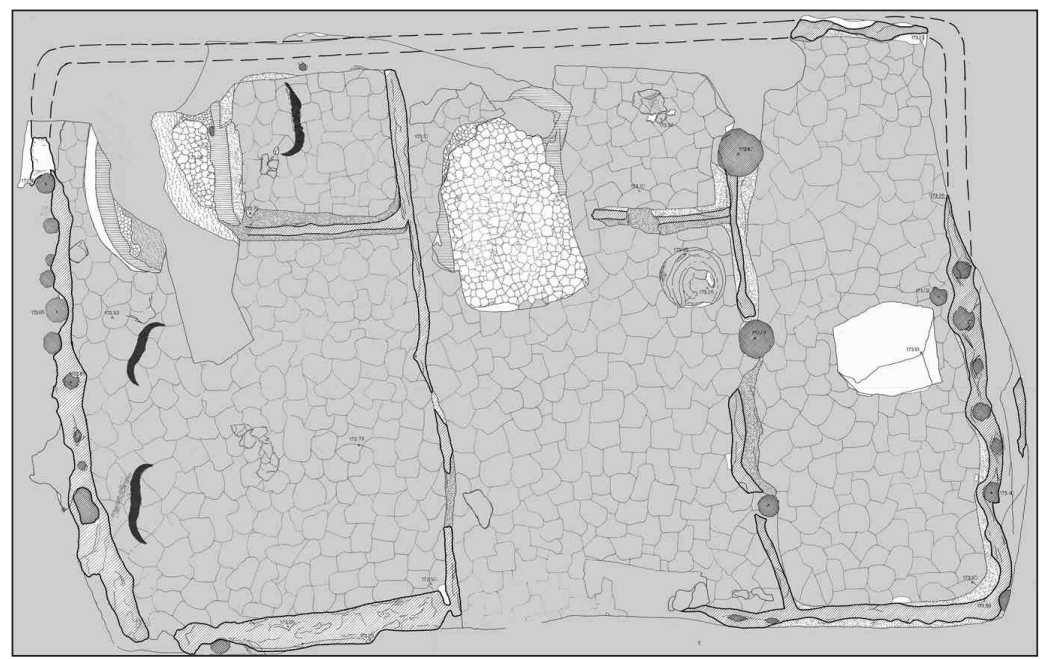

Fig. 2. Late Neolithic Vinča culture house 2/79 at Banjica.

\footnotetext{
6 There are numerous examples of bucrania being placed in other contexts also, such as burials, house foundation deposits, pits etc. (cf. Russell 2012.99, 106). The evidence for this practice among Vinča communities is scarce. One or two cattle bucrania are reported from dug-out pits at Gomolava. The placement of the heads of other species is reported from dug-out pits in Vinča culture settlements also: deer head with horns is found at Gomolava (Orton 2008.302), dog skulls were found at Petnica, Gomolava, Opovo (Orton 2008.168, 273, 305) and Belgrade fortress; several sheep heads with completely preserved horns were found during rescue excavations at Pavlovac-Čukar.
} 
tle slope in the vicinity of the Serbian capital, Belgrade (Todorović, Cermanović 1961; Todorović 1981; Tripković 2007). Based on material culture, the Neolithic settlements at Banjica could be dated roughly to the period 4900-4600 BC. Three sets of entirely preserved cattle horns (two also had preserved head frontlets) were found in the southern room of house 2/79 (Fig. 2). The house is rectangular, with three rooms. One pair of horns was found in a small south-western compartment in the southern room, which probably served as storage. In addition to cattle horns, several pithoi were also found here. Two pairs of horns with head frontlets were found in the central area of the southern room. Both were oriented with horn tips pointing north. The southern room contained a small oven and numerous ceramic vessels for storing, preparing and consuming food. All three sets of horns were possibly left in the house upon abandonment. None are preserved today.

\section{Gomolava}

Gomolava is a tell site on the bank of the Sava River, near the village of Hrtkovci. It has cultural horizons which correspond to the Vinča B-D development phases (Brukner 1980; Jovanović 2011). The site was occupied almost without a significant hiatus from the Late Neolithic until the Roman period. According to AMS dating, the Late Neolithic sequence at Gomolava is dated to $4950-4650$ calBC (Boric 2009.221-227). Judging from the few reports, eight bucrania were recovered from the 1955-1980 excavations (cf. Jovanović 2011.34-35).

Two entirely clay modelled bucrania were found in house 6/1956. The first bucranium, with a pronounced muzzle and eyes represented by circular lines (Fig. 3) was found inside the house, at the entrance to room 3 (Jovanovic 2011.34). This bucranium resembles some hybrid human/animal representations. The second bucranium was probably hung at the entrance to the house.

Two entirely clay modelled bucrania were recovered from house 4/1975 (Fig. 4). The house is rectangular, with three rooms, and dated to late Vinča culture (Petrović 1992). Both bucrania are very small (no larger than a fist) and similar in shape, with muzzle, eyes and small horns/ears being represented. The

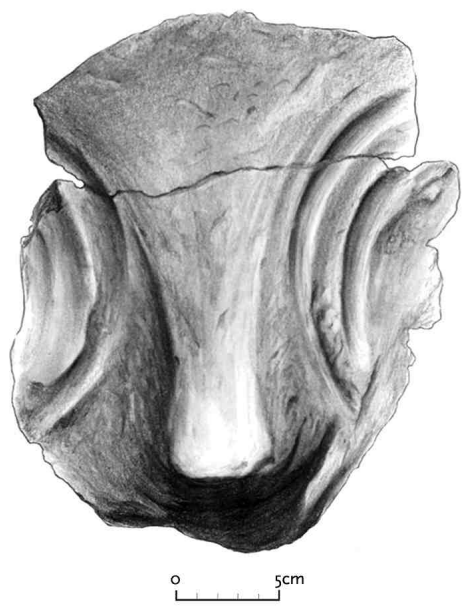

Fig. 3. Bucranium from house 6/1956 at Gomolava.

first was found near the oven in the central room and was probably hung on a wooden post (Fig. 4.2). The second was recovered from the mass of the collapsed wall, one metre from the northern room; it is suspected that it was hung on the outer wall of the house (Fig. 4.1). ${ }^{7}$

Two more bucrania were found in rectangular, above ground building marked as 6/1980 (Brukner 1988.Abb.2, T.3.7-8; Jovanović 2011.31, Fig. 10). The smaller, entirely clay modelled bucranium was found in room 1 in the vicinity of the partition wall shared with room 4 (Fig. 5.2). The second $b u$ cranium - a skull plastered with clay, no longer preserved protruding horns (Fig. 5.1) - was found in room 3 in the same line as the first one, that is near the partition wall with room 4 (Jovanovic 2011.31). Both bucrania have representations of the eyes, snout and nostrils.

\section{Jakovo}

Jakovo-Kormadin is a single-layered Late Vinča culture site near the Serbian capital, Belgrade (Jovano-

7 The second bucranium could also belong to a different, partially excavated house situated near house 4/1975 (based on information from Marija Jovanović, curator of the Gomolava collection in the Museum of Vojvodina in Novi Sad). 
vić, Glišić 1960). Two houses, several pits and a segment of a defensive ditch were discovered in the course of the 1956-1960 excavations. Based on material culture and relative chronology, the settlement could be dated roughly to the period between 4750 and $4600 \mathrm{BC}$. Three bucrania were recovered from the site.
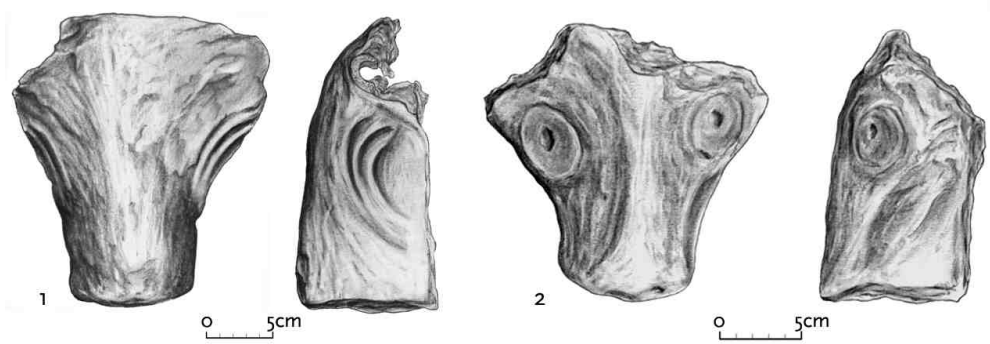

Fig. 5. Bucrania from house 6/1980 at Gomolava.

Two bucrania were found in house $1 / 1957$. The house was rectangular, and probably had two rooms with decorated walls, one oven, and one large rectangular clay structure with horn-like endings which was interpreted as an altar (Jovanović, Glišić 1960. 132, Fig.33, 35). The house was burnt and probably cleaned before demolition, so only several whole vessels, as well as one anthropomorphic clay figurine and one clay object in the form of a so-called $\mathrm{Y}$ amulet were found on the house floor (Jovanovic, Glišic 1960.125, Fig.18). The first bucranium was found in the southwestern part of the house (Fig. 6.1) - a cattle head frontlet plastered with clay; no horns were preserved, and considering the pentagonal shape of the bucranium, which resembles some hybrid human/ animal representations, it probably never had horns. The eyes are represented by small circular imprints, above and beneath which are slightly curvilinear lines. During the excavations, facial hairs from the cattle head were still visible protruding from the mass of clay (Jovanović, Glišić 1960.131). The reverse side of the bucranium bears a trace of a wooden beam, so it was probably hung on a wooden post. Judging from the diameter of the imprint of the wooden beam on the back of the $b u$ cranium, the excavators suggested that it probably stood in the northern section of the house, where traces of a similar wooden post were observed ( $\mathrm{Jo}$ vanović, Glišić 1960.131, Fig. 33). The second bucranium was found in the northern room, near fragments of decorated daub wall (Fig. 6.2). It is heavily fragmented, with only the elongated nose with nostrils being preserved. Part of the bone is still visible at the rear.

The third Jakovo bucranium was found in house 2/1958 (Jovanović, Glišic 1960.129). The house is rectangular, and is a typical Vinča culture above-ground building with three rooms. It belongs to the first type of bucranium with clay plastered cattle skull. It originally had both horns, which were in a very bad sta- te of preservation even during the excavations. The bucranium was found facing upwards, in the central room, associated with the oven. Judging from the imprint of the wooden plank and ropes on the reverse side of the bucranium, a skull with horns was first tied to a low daub construction near the oven, and then plastered with clay. Only the eyes are represented by spiral circular lines (Fig. 7). Both horns and bucranium are now missing.

\section{Jela-Benska bara}

The site of Benska bara near the town of Šabac is situated on a small river terrace, once surrounded by swamps on three sides (Trbuhović, Vasiljevic 1983. 26; Stojić, Cerovic 2011.149-173). The site is dated to the Late Neolithic Vinča culture, as well as the Late Eneolithic Baden culture. Numerous ceramic vessels decorated in the manner of Tisza culture have also been detected in three superimposed Vinča culture settlement layers. Two bucrania were recovered from the site. The first is an almost complete aurochs skull with horns found on the floor of one of the above-ground Vinča houses (Fig. 8). The second, badly preserved, is completely made of clay; it was also found on the house floor (Fig. 9).

\section{Stubline}

Based on current information, Stubline is a multi-layered Late Vinča site on an elevated slope (Todorovic 1967). New excavations, as well as a geo-physical survey revealed that the settlement is exceptionally well-preserved, with more then 200 aboveground houses and circular ditches surrounding it (Crnobrnja et al. 2009). Four bucrania were found

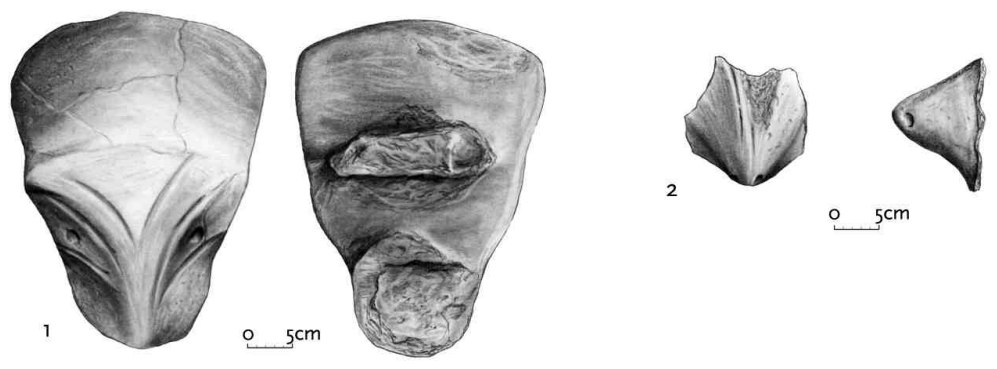

Fig. 6. Bucraniua from house 1/1957 at Jakovo. 


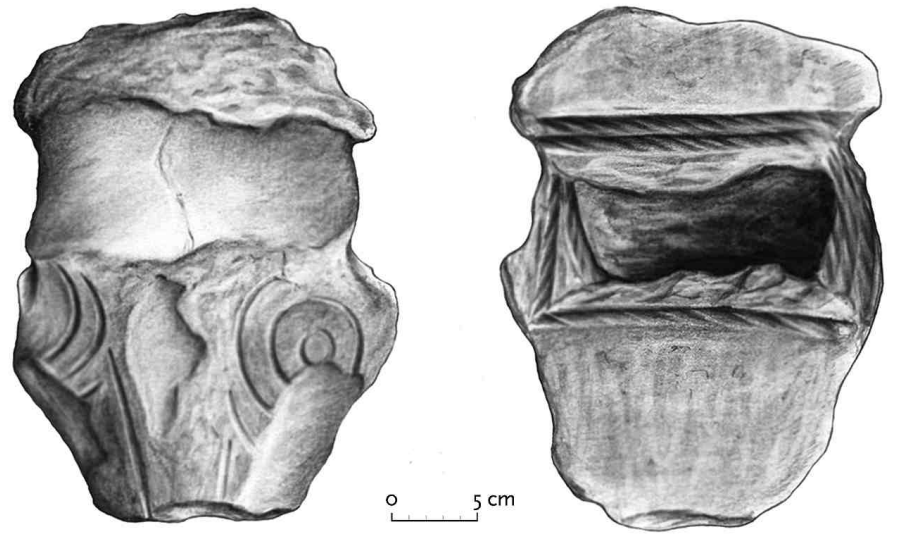

Fig. 7. Bucranium from house 2/1958 at Jakovo.

in two houses excavated in the course of the 2008 and 2010 excavations.

One bucrania made entirely of clay was found in house $1 / 2008$. The house is rectangular, with no apparent subdivision of rooms. The house inventory was remarkably well-preserved, with two ovens, a quern, a clay structure for cereal storage (interpreted as an altar in the initial publication), dozens of ceramic vessels, 43 figurines and 11 miniature tool models. The bucranium was found in the central part of the house, and is quite unique. Careful examinations during the reconstruction showed that the stylised horns and snout were modelled on a flat clay board (Fig. 10). There are no structural elements suggesting that the bucranium was hung on a post or some other structure; therefore it was probably portable.

Three more bucrania were found in house $2 / 2010$. The house is also rectangular, with no detected subdivision of the interior. The house has a massive clay floor and numerous well-preserved structures and finds (two ovens, one clay structure for cereal storage, a clay table, one quern, a large number of storage vessels, etc.). Two bucrania found facing the

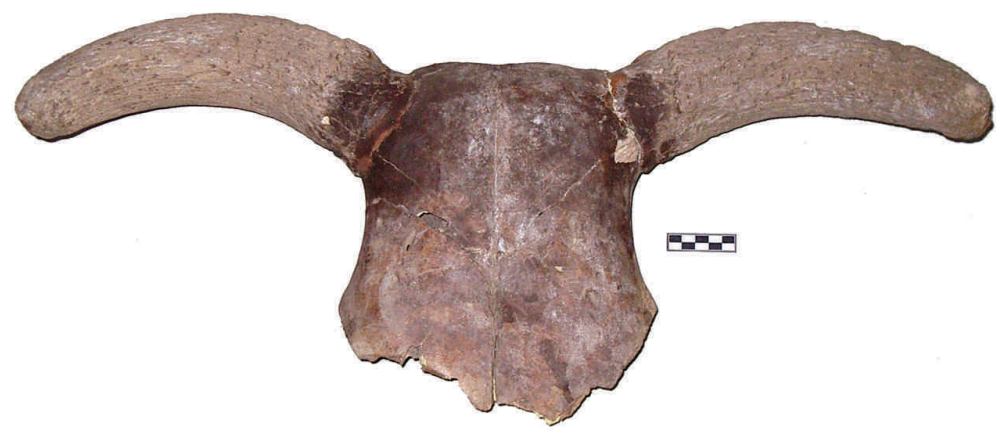

Fig. 8. Bucranium from Jela-Benska bara. floor were associated with a large oven in the northeastern part of the house. The first was $30 \mathrm{~cm}$ from the mouth of the oven (Fig. 11.2). The snout is clearly defined, while the eyes are represented with low linear finger impressions. It has an elongated and pronounced forehead, thus resembling the $b u$ cranium from Jakovo, as well as heads of some small hybrid human/animal and anthropomorphic representations. Small fragments of the skull can be seen protruding from the clay. The imprint of a wooden post and rope are visible on the reverse side of the bucranium. Post holes were not detected in the vicinity of the place of find. The second bucrania is entirely made of clay. The head is wider, and the snout is even clearly defined (Fig. 11.1). It was found $70 \mathrm{~cm}$ west from the mouth of the oven, in the vicinity of a triangular post hole and ceramic quern. The third bucranium is entirely made of clay, and was found in a mass of collapsed wall fragments in the southern part of the house, which is heavily damaged. It has a marked snout, and eyes represented by concentric circular lines (Fig. 11.3). It also resembles the heads of some small hybrid human/animal and anthropomorphic representations.

\section{Figurines}

Zoomorphic figurines are the most common media of animal imagery in the Late Neolithic Vinča culture. The main attributes of animal figurines include: use of clay as raw material; miniature dimensions (often no larger than $5-8 \mathrm{~cm}$ ); schematisation and abstraction in the representation of animal species and gender. As noted above, clay is the most frequently used raw material for the production of both human and animal figurines in Vinča culture. Further studies of zoomorphic imagery should address the question of why only one type of extremely schematised zoomorphic figurine was modelled in stone. This type of figurine appears throughout the Vinča culture territory, from the sites in southern Serbia (Pavlovac, Crnokalačka Bara, Pločnik) to the Pannonian plain in the north (Vinča, Botoš).

Although animal figurines are usually quite small, some examples are significantly larger. 8 Unlike in the case of raw material selection, the

8 New rescues excavations carried out at the site at Pavlovac-Čukar in southern Serbia revealed several bull figurines with the heads alone measuring more than $10 \mathrm{~cm}$ long. 
variability in dimensions of both anthropomorphic and zoomorphic figurines differs - in terms of regional settings, with southern Serbia (Morava valley and Kosovo and Metohija mainly) being the area where larger figurines were most often produced. Perception and observation of scale is something that is exhibited in various ways in material culture (Bailey 2005.26-34). Thus, the size of figurines is certainly somehow related to the various ways of emphasising and negotiating social identities specific to regions and settlements. The question of abstraction and schematisation in anthropomorphic and zoomorphic figurines has already been briefly addressed. The representation of bovine figurines in the Late Neolithic Vinča culture is usually realistic, at least when the whole figurine survives. Thus the schematisation of zoomorphic imagery applies mainly to other species. It should also be stressed that detailed representations of any anatomical characteristics such as eyes, mouth, teeth, fur, skin, or claws9 are absent in the whole corpus of animal figurines in Vinča culture. Intriguingly, detailed depictions of anatomical parts of the body, clothing and jewellery are commonly present on anthropomorphic figurines. This could lead to the assumption that anthropomorphic figurines were projected to accumulate things that are essential for visual communication, while animal figurines (including bovine examples) were intended for more tactile interaction ( $c f . N a k a$ mura, Meskell 2006.182).

Cattle figurines are quite often found in Vinča settlements. Unlike any other cattle representation, figurines are modelled very realistically, with horns, four legs and a typically male body. Gender characteristics (mainly male genitals) are also often modelled. Bull figurines are small (up to $5 \mathrm{~cm}$ high and $10 \mathrm{~cm}$ long), although there is evidence for larger specimens. Like human figurines, they are found in various contexts. Perhaps of the greatest importance in understanding the meaning of bull figurines is their occurrence in contexts with thermal structures in a house, as presented by finds at the Belovode settlement (Šljivar, Jacanović 2005), which could have been inhabited from 5350 to $4650 \mathrm{BC}$ (Borić 2009.209). Four out of seven bovine figurines were found in a clear context, near the southern wall of oven 1, in one above-ground house, while the other three specimens were recovered from a deeper layer of the same trench (Šljivar, Jacanović 2005.71-73).

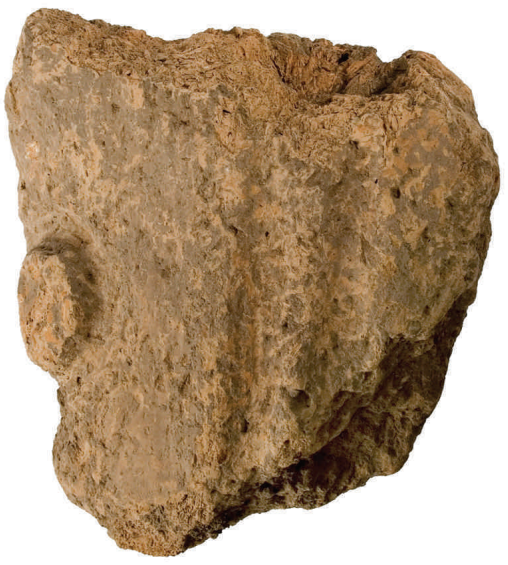

Fig. 9. Bucranium from Jela-Benska bara.

The group of four figurines found near the oven is said to represent two bulls, a cow and a calf (Šljivar, Jacanovic 2005.72). It is also said that among the 7 figurines, two species of ancient domesticated cattle could be identified: Bos primigenius and Bos brachyceros (Šljivar, Jacanović 2005.75). Regarding the group of four figurines associated with the oven: two have male genitalia, one of which has a perforation on the snout; three are similar in size, one considerably smaller (Figs. 12, 13); of the finds from the cultural layer, two out of three figurines have male genitalia, one of which has a perforated snout. All 7 figurines are realistically modelled and all have broken horn tips.

An interesting issue concerning bull figurines is the question of their fragmentation. Almost all the figurines I have had the chance to see have broken horn tips, which in many cases certainly was not the result of clumsiness and/or careless handling by Vinča people and such fragmentation is not the result of post-depositional effects. Therefore, as in the case of

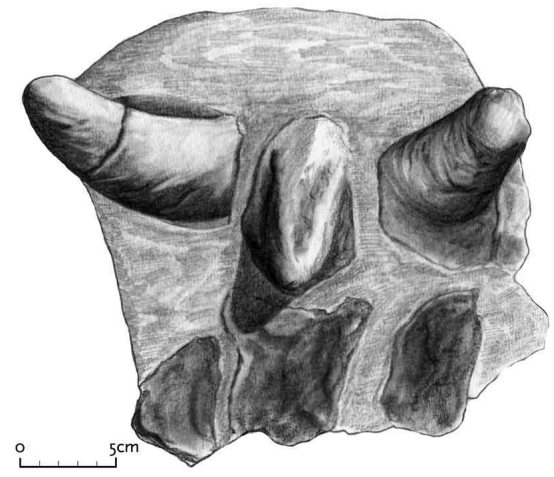

Fig. 10. Bucranium from house 1/2008 at Stubline.

\footnotetext{
9 Some quadruped figurines from the site at Pavlovac-Čukar have incisions on the body which probably represent textile draped over the body of animal rather than depicting animal fur or skin pattern. It could also depict ceremonial painting on the animal's body.
} 
anthropomorphic figurines (cf. Talalay 1987; Chapman 2000.55-79; Chapman, Gaydarska 2007.113-143), the practice of breaking the horns of bull figurines is undoubtedly closely connected with social practice, ideology and various other social agents in Vinča culture. Thus the fragments could have operated as a part of a broader idea or
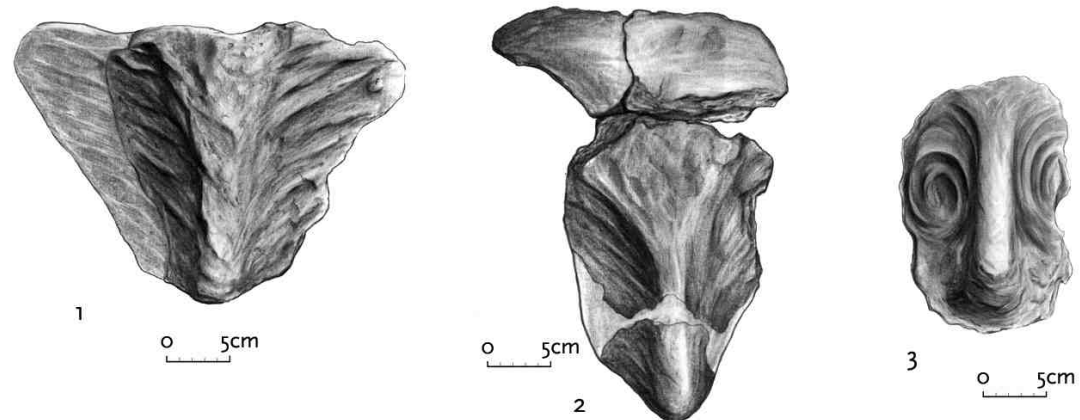
concept of humanity/animality. Fragmented bovine figurines could also have imbedded properties as a whole, but lose some of their original meaning in the course of symbolic breakage.

\section{Ceramic vessels}

The third category of bovine representations consists of various motifs associated with ceramic ves-

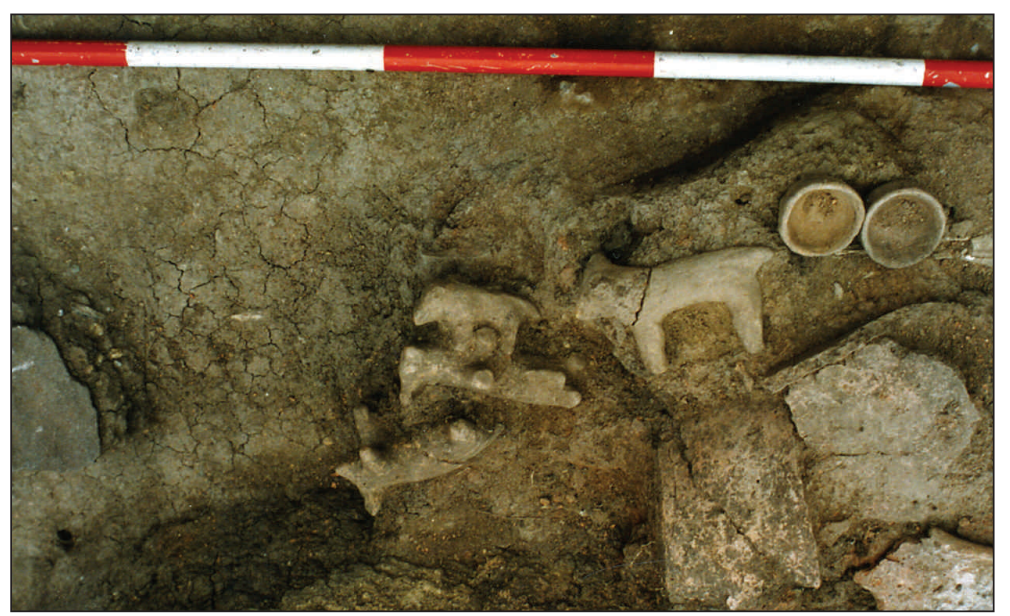

sels. The most common are stylised bull protomes on the handles of smaller vessels probably used for liquid consumption. These are usually very schematic representations of bull's head and horns (Fig. 14). It is worth noting that those finds very often have long biographies. If the vessels breaks, the handle with protome continues to be used as a polisher for a long time afterwards.10 Bull heads modelled on the exterior of vessel walls are rarely found (Fig. 15). The only reported example comes from the late Vinča house at Obrež-Beletinci (Jovanović 2011.35, Fig.12). The third category includes incised abstract bull representation on the exterior walls of vessels. One example is a schematised linear bull representation on the exterior wall of a ceramic bowl from the site at Banjica (Fig. 16). These incised abstract scenes have been interpreted as a sign of property. More absurdly, these representations have also been interpreted as proof of the beginning of literacy in Vinča culture. My cur-

Fig. 12. Clay bull figurines found in the oven at Belovode.

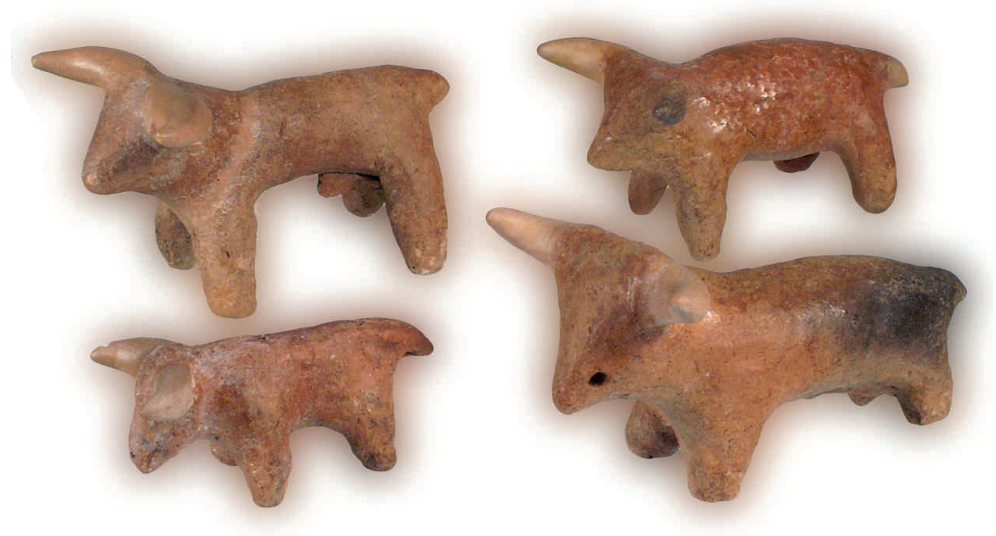
rent analysis shows that many of these images are mainly associated with animal symbolism, which certainly has nothing to do with literacy.

Vessels in the form of animal bodies are extremely rare in Vinča culture; so far only few such finds were reported, with birds being the most frequently depicted species $(c f . \mathrm{Ni}$ kolić, Vuković 2008a.175-179; $2008 b$ ). Only one possibly bull-shaped ceramic vessel is known from the site at Vinča (Ignjatovic 2008. Fig. 13. Clay bull figurine from Belovode. 257, kat. 162). The vessel is shaped

10 This practice of secondary usage is also observed among other types of handles on ceramic vessels, so it need not be associated with symbolic activity. 


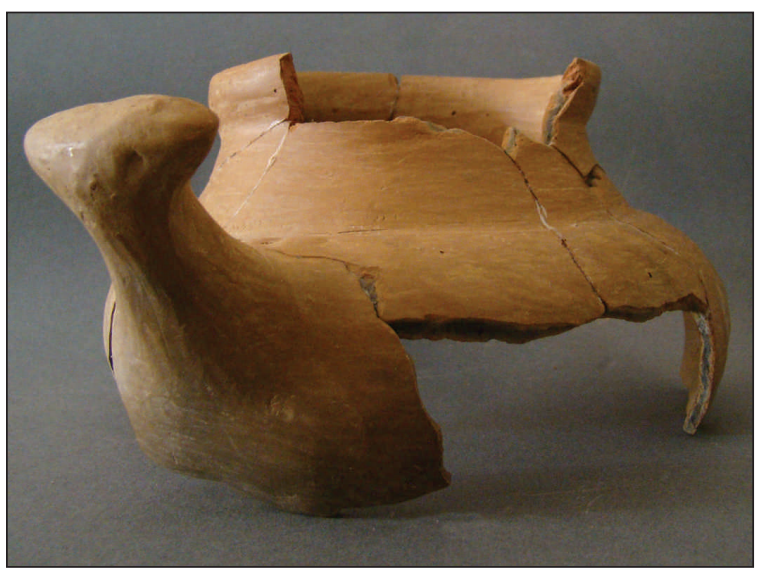

Fig 14. Bowl with schematised representation of a bull's head on the handle from Belgrade fortress.

in the form of a quadruped with two horns on the head; the opening of the vessel is on the back of the animal's body. Plastically applied clay straps are modelled on the neck and sides of the body. Thus the applied straps associated with the vessels mouth on the back appear to be representing some sort of fastenings for carriage put on the animal's back.

So-called altars or cult tables also fall into the group of ceramic vessels with animal representations. Animal protomes are most frequently placed in the corner of rectangular shallow recipients. The depiction usually includes only the head, which is so ambiguously represented that it is impossible to say with certainty whether some anatomical details represent ears or horns, snout or beak. Thus many interpretations of the precise animal species on the socalled altars are fruitless. Even in cases when there is some kind of broad scientific agreement - such as that the animal represented on the so-called Gradac type altars is a red deer/stag (Jovanovic 1982.49; 2006.224-225; Borić 2009.204) - it could equally be the representation of some other horned mammal, such as bull, ram, goat (cf. Perić 2006.243, Pl. V/35, 36).

The whole corpus of bovine representations on ceramic vessels consists mainly of stylised bull representation. Further studies should address the question of the relationship between ceramic vessels and bull representations at more levels. Although the fact that women in prehistory are usually associated with the process of making and decorating ceramic vessels is merely heuristic, if we accept it only as a working thesis, then the process of introducing typi- cally male symbols such as bulls into the sphere of female activity has to be studied in the line of negotiating male/female relations. Thus due to the ambiguity in representations we could also question male/ female interactions. Considering the relationship between bovine imagery and ceramic vessels, a reasonable line of inquiry would also be to perceive animal bodies as capable of holding substances, so there could be a connection between certain types of substances and certain animal species depicted on ceramic containers (sensu Nanoglou 2008a.200, 201). Still, this is only a good way to think of animal representations, because linking particular animal species with particular substances by means of pottery is rather difficult, given the ambiguity and vagueness of depiction.

\section{Bovines in Vinča culture: good to eat and good to think11}

The eyes and the heart are sad, but the teeth and the stomach are glad. (Evans-Pritchard 1940.26)

The quote from E. Evans-Pritchard's seminal work on the Nuer cattle herders of Central/Eastern Africa (Sudan) properly sets out the agenda for the discussion of human/cattle relationship. Cattle are highly valued among the Nuer both symbolically and nutritionally (Evans-Pritchard 1940.16-51). They had enormous economic significance in the Late Neolithic Vinča culture also (Russell 1998.49), and there is no doubt that cattle had potent symbolic value. Bovine symbolism was both of public and private concern. Cattle bucrania placed inside the house,

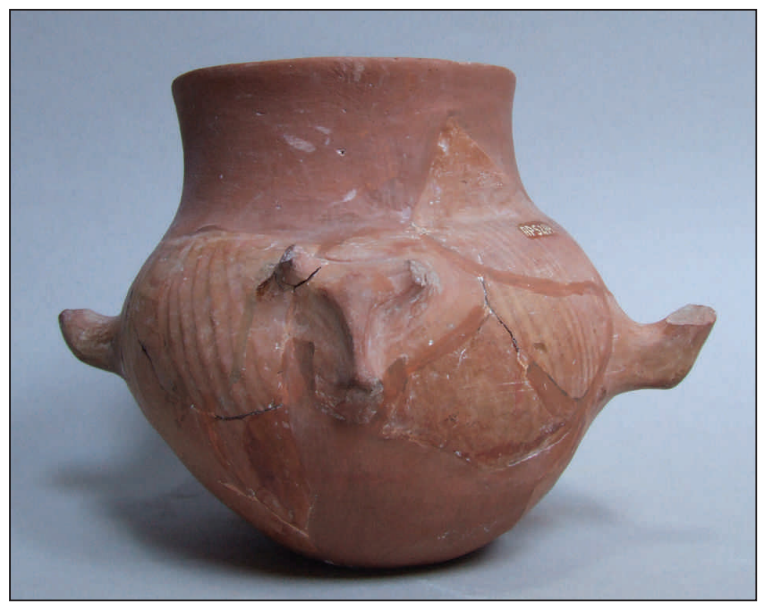

Fig 15. Bowl with bull's head on the wall from $\mathrm{Ob}$ rež-Beletinci.

11 The famous Lévi-Strauss's statement that animals are both good to eat and good to think with (Lévi-Strauss 1964.89) influenced broad range of scholars dealing with human/animal relationship. The sentence is often cited in various ways (cf. Whittle 2003. 78, 94, 95; Russell 2012.340). 
near the oven, certainly had a more private character, and were probably somehow included in symbolic structuring. Bucrania were probably thus used as instruments to recount and curate household/ancestral narratives. This claim could be further reinforced in the light of the placement of bucrania near the

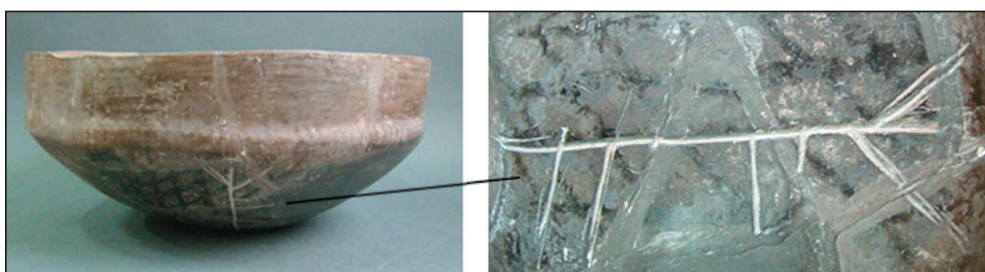

Fig. 16. Bowl with incised schematic representation of bull from Banica. oven, especially taking into the account their association with the main supportive beam as attested in houses 1/1957 at Jakovo, 4/ 1975 at Gomolava and $2 / 2010$ at Stubline. Thus the symbolic potency of bucrania can be perceived considering their relation with the main structural element of the house. Such a dichotomy points to the perception of the $b u$ cranium as the most important symbolic precursor enabling life in the house. Further associations of bucrania and supportive beams with hearths and ovens delineate these house areas as focal mnemonic loci commemorating house narratives. In the course of the house histories, these areas were the main arenas for establishing and negotiating social and gender identities.

There is an interesting shift regarding cattle symbolism and bucrania in Vinča culture. The number of real clay-plastered cattle skulls with protruding horns decrease in the Late Vinča culture. Instead, entirely clay modelled bucrania with less prominent bovine attributes were introduced into household narratives. Bucrania became more hybrid, resembling a similar representational shift in anthropomorphic imagery. Except in the case of the bucranium from house 1/2008 at Stubline, the change in iconography was not the result of reducing the physical properties of the imagery while retaining its symbolic value. The change was both in physical and symbolic manifestation of representations. Still, the new bucrania with ambiguous anthropomorphic, bulllike, deer-like features were employed at the same place and probably in the same way as previous ones. Thus, the change in iconography of the bucrania perhaps signals a broader cultural transformation in Vinča culture. Were these perhaps economic or symbolic transformations? However, none of the Late Vinča culture sites has shown a significant decline in domestic cattle numbers, or a shift in orientation towards specific animal species or in the wild/ domestic ratio.12 Thus the change in the representational paradigm of bucrania must be explained by addressing other questions besides the change in economy. The question of placing two bucrania inside houses at Stubline and Jakovo should also be addressed. This practice is particularly important because two types of bucrania are engaged - one with clear bull representations, and the second with the attributes of some hybrid anthropomorphic creatures typical of small clay figurines. Such symbolic structuring of bull and human imagery calls for a reconsideration of symbolic dualism in Vinča culture and both human and non-human Umwelt (sensu Sebeok 1988.66; Willis 1994.10, 11).

As just sketched above, there are numerous ways to think in terms of bovine/human relationship; as a final excursus, I will briefly aim at two more concepts relating to this issue.

One of the most prominent ways of understanding bovine iconography in Vinča culture is to follow the structuralist approach of Ian Hodder in his seminal books The Domestication of Europe and Symbols in Action (Hodder 1981; 1990). ${ }^{\mathbf{1 3}}$ As in no other Neolithic contexts, we can clearly delineate the concept of opposed structures in Vinča culture: 'inside/ outside; domestic/wild; female/male; domus/agrios; human/animal'. To put it simply, if there is symbolic structuring among Vinča culture communities, and there certainly is (at least in the case of material culture), there should be corresponding relations between oppositional structures. Therefore, as inside is opposed to outside, domestic to wild, female to male, domus to agrios, so should notions of inside, domestic, female and domus be somehow connected, as well as outside with wild, male and agrios. There is a strong connection between the house, the domestic sphere and woman, as there is between man, wild and forest in Vinča culture. But in the case of cat-

12 There are some subtle changes, $e . g$., the number of cattle increases slightly during the 100-200 years of occupation at Opovo (Russell 1998.50).

13 Although the domus/agrios thesis has been much debated recently (cf. Thomas 1991.14; Whittle 2003.93; Russell 2012. 246-247), despite some shortcomings and limitations, the concept has enormous interpretative potentials and is used here to demonstrate the myriad ways of looking at human-animal relations. 
tle in Vinča culture, all supposedly opposed structures are interwoven. Men are in the house, so are the bull bucrania and wild bull figurines. On the other hand, cattle astragali were used as loom weights (Blažić, Radmanović 2011) as well as bull decoration on ceramic vessels as part of the male symbolic repertoire are introduced into the female part of the social arena. Therefore, bovine iconography was probably included in the process of shifting and negotiating social and gender identities among Vinča culture communities. Still, such structuring, especially in terms of spatial house division according to age and gender, has not been observed, at least not in the sense of clearly delineated and restricted house areas (cf. Borić 2005.62-64, Fig. 20). Then, as already mentioned, symbolic structuring concerning bovine iconography in Vinča culture is to be sought as a paradigm of both gender and age cohesion, as well as a signal of subtle segregation.

Thinking in terms of actual human/animal relationships offers a far more challenging perspective. I argue that every notion of animal, in our case bovines, whether we are dealing with animals as symbols or animals as food, is deeply embedded in the human perception of the animal world. And, by the animal world, I mean the same world that humans inhabited and shared with other non-humans. Also, I am quite sure that one should not neglect the purely physical, visceral connection and experience that people had with animals, as well as emotions that grew out of that connection. The pain caused by injury during the hunt, the smell of cow dung, the song of the bird, all influenced basic ideas and notions that shaped and transferred animals into powerful symbols in human culture.

At the moment, I can only suggest how cattle became such a strong metaphor in Vinča culture. In case of domesticates, like other tamed animals, they were introduced into the Vinča community, and thus became an inseparable part of Vinča culture. And conversely, in the case of wild cattle, humans commonly enter their world, considerably influencing the life course of wild animals. The importance of cattle in the economy, their value as a food source and bride-wealth linked them with specific gender, age group and temporal events, thus becoming essential in symbolic structuring among Late Neolithic Vinča culture communities.

$$
\text { ACKNOWLEDGEMENTS }
$$

I would like to thank Professor M. Budja for the splendid opportunity to take part in 18 th Neolithic Seminar in Ljubljana. Gratitude also goes to several colleagues in Serbia who generously opened the doors of their museum collections: Marija Jovanovic at the Museum of Vojvodina in Novi Sad, Momir Cerovic at the City museum of Šabac, and Duško Šljivar at the National museum in Belgrade. Comments on an early draft of this paper made by assistant Professor Milos Jevtic at the Archaeology Department at the Faculty of Philosophy in Belgrade were thoughtful and helping as usual. Responsibility for all errors and misinterpretations in the paper is mine alone.

\section{References}

Antonović D. 2003. Neolitska industrija glačanog kamena u Srbiji. Arheološki institut. Beograd.

Bailey D. 2005. Prehistoric Figurines: representation and corporeality in the Neolithic. Routledge. London.

Bailey D., Cochrane A and Zambelli J. 2010. Unearthed: a comparative study of Jōmon Dogū and Neolithic figurines. Sainsbury Centre for Visual Arts. Norwich.

Binford L. 1981. Behavioral Archaeology and the 'Pompeii Premise'. Journal of Anthropological Research 37(3): 195-208.
Blažić S., Radmanović D. 2011. Loom weights made of astragali. In M. Jovanović (ed.), Masters of clay and wheat. Muzej Vojvodine, Novi Sad: 128-143.

Bökönyi S. 1988. The Neolithic fauna of Divostin. In A. McPherron, D. Srejović (eds.), Divostin and the Neolithic of Central Serbia. University of Pittsburgh, Pittsburgh: 419-445.

Borić D. 2005. Body metamorphosis and animality: volatile bodies and boulder artworks from Lepenski Vir. Cambridge Archaeological Journal 15: 35-69. 
2009. Absolute Dating of Metallurgical Innovations in the Vinča Culture of the Balkans. In T. L. Kienlin, B. Roberts (eds.), Metals and Societies: Studies in honour of Barbara $S$. Ottaway. Universitätsforschungen zur prähistorischen Archäologie, Bonn: 191-246.

Brukner B. 1980. Naselje Vinčanske grupe na Gomolavi: neolitski i ranoeneolitski sloj. Izveštaj sa iskopavanja 1967-1976. g. Rad Vojvođanskih Muzeja 26: 5-55.

1988. Die siedlung der Vinča-gruppe auf Gomolava (die Wohnschicht des Spätneolithikums und Frühaneolithikums (Gomolava Ia, Gomolava Ia-b und Gomolava Ib)) und der Wohnhorizont des aneolithischen Humus (Gomolava II). In N. Tasić, J. Petrović (eds.), Gomolava: Chronologie und Stratigraphie der Vorgeschichtlichen und Antiken Kulturen der Donauniderung und Südosteuropas. Vojvođanski muzej, Balkanološki institut SANU, Novi Sad: 19-38.

Budja M. 2003 Seals, contracts and tokens in the Balkans Early Neolithic: where in the puzzle. In M. Budja (ed.), 10th Neolithic Seminar. Documenta Praehistorica 30: 115-130.

Chapman J. 2000. Fragmentation in archaeology. People, places and broken objects in the prehistory of South Eastern Europe. Routledge. London and New York.

Chapman J., Gaydarska B. 2007. Parts and Wholes: fragmentation in prehistoric context. Oxbow Books. Oxford.

Clason T. 1979. The farmers of Gomolava in the Vinča and La Tene period. Rad Vojvođanskih Muzeja 25: 60-114.

Crnobrnja A., Janković M. and Simić Z. 2009. Late Vinča culture settlement at Crkvine in Stubline: Household organization and urbanization in the Late Vinča culture period. Starinar LIX: 9-25.

Dimitrijević V. 2006. Vertebrate fauna of Vinča-Belo Brdo (Excavation Campaigns 1998-2003). Starinar LVI: 245269.

Evans-Pritchard E. E. 1940. The Nuer: A Descriptions of the modes of Livehood and Political Institutions of a Nilotic People. Clarendon Press. Oxford.

Garašanin D. 1951. Neolitska kamena plastika u Srbiji. Starinar II: 7-12.

Greenfield H. 1986. The Paleoeconomy of the Central Balkans (Serbia). British Archaeological Reports. Oxford.

Gimbutas M. 1982. The Goddesses and Gods of Old Europe, 6500-3500 BC, Myths and Cult Images. University of California. Berkley.
Hodder I. 1981. Symbols in action: ethnoarchaeological studies of material culture. Cambridge University Press. Cambridge.

1990. The Domestication of Europe: Structure and Contingency in Neolithic Societies. Blackwell. Oxford.

Humphrey N. 1984. Consciousness Regained: Chapters in the Development of Mind. Oxford University Press. Oxford.

Ignjatović M. 2008. Katalog. In D. Nikolić (ed.), Vinča praistorijska metropola. Filozofski fakultet univerziteta $\mathrm{u}$ Beogradu. Narodni muzej u Beogradu. Muzej grada Beograda, Beograd: 203-281.

Ingold T. 1983. The Architect and the Bee: Reflections on the Work of Animals and Men. Man N. S. 18(1): 1-20.

2000. The Perception of the Environment: Essays on livelihood, dwelling and skill. Routledge. London and New York.

Jovanović B. 1982. Rudna Glava. Najstarije rudarstvo bakra na centralnom Balkanu. Arheološki institut. Beograd.

2006. Gradac Phase of the Vinča Culture: Origin of Typological Innovation. In N. Tasić, C. Grozdanov (eds.), Homage to Milutin Garašanin. Serbian Academy of Science and Arts, Macedonian Academy of Sciences and Arts, Belgrade: 221-235.

Jovanović B., Glišić J. 1960. Eneolitsko naselje na Kormadinu kod Jakova. Starinar XI: 113-140.

Jovanović M. 2011. Masters of clay and wheat. Muzej Vojvodine. Novi Sad.

Lévi-Strauss C. 1964. Totemism. Merlin Press. London.

Marangou C., Grammenos D. 2005. 'Monumentality', Functionality, Animality: On an Unusual Prehistoric Clay Head from Central Macedonia, Greece, and Its Implications. The Annual of the British School at Athens 100: 1-40.

Mlekuž D. 2007. 'Sheep are your mother': rhyta and the interspecies politics in the Neolithic of the eastern Adriatic. In M. Budja (ed.), 14th Neolithic Seminar. Documenta Praehistorica 34: 267-280.

Nakamura C., Meskell L. 2006. Figurine Report 2006. Archive Report on the Catalhöyük Season 2006. Online www.catalhoyuk.com.

Nanoglou S. 2008a. Representation of humans and animals in Greece and the Balkans during the earlier Neolithic. Cambridge Archaeological Journal 18: 1-13. 
2008b. Qualities of Humanness: Material Aspects of Greek Neolithic Anthropomorphic Imagery. Journal of Material Culture 13: 311-334.

2009. Animal Bodies and Ontological Discourse in the Greek Neolithic. Journal of Archaeological Method and Theory 16: 184-204.

Nikolić D., Vuković J. 2008a. Čuvari i zaštitnici: kultni predmeti. In D. Nikolić (ed.), Vinča - praistorijska metropola. Filozofski fakultet univerziteta u Beogradu. Narodni muzej u Beogradu; Muzej grada Beograda, Beograd 2008: 165-179.

2008b. Vinča Ritual Vessels: Archaeological Context and Possible Meaning. Starinar LVIII: 51-69.

Orton C. D. 2008. Beyond Hunting and Herding: Humans, animals, and the political economy of the Vinča period. Unpublished PhD thesis. University of Cambridge. Cambridge.

Parker-Pearson M., Richard C. 1997. Ordering the world: Perception of architecture, space and time. In M. ParkerPearson, C. Richards (eds.), Architecture and Order: Approaches to Social Space. Routledge, London and New York: 1-33.

Perić S. 1996. Kulth-Rhytone der neolitischen Viehzüchter der Balkanhalbinsel. Starinar XLVII: 21-66.

2006. The Gradac Period in the Neolithic Settlements in the Middle Morava Valley. In N. Tasić, C. Grozdanov (eds.), Homage to Milutin Garašanin. Serbian Academy of Sciences and Arts, Macedonian Academy of Sciences and Arts, Belgrade: 235-251.

Petrović J. 1992. Arhitektura kuće 4 na Gomolavi: naselje mlađe Vinćanske kulture. Rad Vojvođanskih Muzeja 34: $19-32$

Russell N. 1998. Cattle as wealth in Neolithic Europe: where's the beef? In D. Bailey (ed.), The Archaeology of Value: Essays on Prestige and the process of valuation. BAR IS 730, Oxford: 42-54.

1999. Symbolic dimensions of animals and meat at Opovo, Yugoslavia. In J. E. Robb (ed.), Material Symbols: culture and economy in prehistory. Southern Illinois University, Carbondale: 153-172.

2012. Social Zooarchaeology: Humans and Animals in Prehistory. Cambridge University Press. Cambridge.
Sebeok T. A. 1988. 'Animal' in biological and semiotic perspective. In T. Ingold (ed.), What is an animal? Routledge, London: 63-76.

Stanković S. 1989-1990. Predstava bika u starijem neolitu. Starinar XL-XLI: 35-43.

Stojić M., Cerović M. 2011. Šabac: Kulturna stratigrafija praistorijskih lokaliteta u Podrinju. Arheološki institut and Narodni Muzej u Šapcu. Beograd and Šabac.

Šljivar D., Jacanović D. 2005. Zoomorphic figurines from Belovode. Zbornik Narodnog Muzeja 18: 69-78.

Talalay L. E. 1987. Rethinking the function of clay figurine legs from Neolithic Greece: an argument by analogy. American Journal of Archaeology 91: 161-9.

Thomas J. 1991. Understanding the Neolithic. Routledge. London and New York.

Todorović J. 1967. Crkvine, Stubline, Obrenovac - naselje vinčanske grupe. Arheološki pregled 9: 17-18.

1981. A recently discovered house in the Neolithic settlement of Banjica in Belgrade. Archaeologica Iugoslavica 18: 13-17.

Todorović J., Cermanović A. 1961. Banjica: naselje vinčanske kulture. Muzej grada Beograda. Beograd.

Trbuhović V., Vasiljević M. 1983. Najstarije zemljoradničke kulture u Podrinju. Narodni muzej Šabac. Šabac.

Tripković B. 2007. Domaćinstvo i prostor u kasnom neolitu: vinčansko naselje na Banjici. Srpsko Arheološko Društvo. Beograd.

Twiss C. K., Russell N. 2009. Taking the bull by the horns: Ideology, Masculinity, and Cattle horns at Catalhöyük (Turkey). Paléorient 35(2): 19-32.

Vuković J. 2005. The Blagotin amulets and their place in the Early Neolithic in the Central Balkans. Glasnik Srpskog arheološkog društva 21: 27-44.

Whittle A. 2003. The Archaeology of People: Dimensions of Neolithic life. Routledge. London and New York.

Willis R. 1994. Introduction. In R. Willis (ed.), Sinifying animals: Human meaning in the natural world. Routledge, London and New York: 1-22. 